\title{
Synthesis, Characterization, and Reactivity Study of Triosmium Acetylide Cluster Complexes Bearing a $\left(\mathrm{C}_{5} \mathrm{Me}_{5}\right) \mathrm{W}(\mathrm{O})_{2}$ Fragment
}

\author{
Chin-Wei Shiu, ${ }^{\dagger}$ Y un Chi ${ }^{*, \dagger}$ Arthur J . Carty, ${ }^{*, \ddagger}$ Shie-Ming Peng, ${ }^{*, \S}$ and \\ Gene-Hsiang Lee§
}

Department of Chemistry, National Tsing Hua University, Hsinchu 30043, Taiwan, Steacie Institute for Molecular Sciences, National Research Council Canada, 100 Sussex Drive, Ottawa, Ontario K1A OR6, Canada, and Department of Chemistry and Instrumentation Center, National Taiwan University, Taipe 10764, Taiwan

Summary: The heterometallic cluster compound $\left(\mathrm{C}_{5}-\right.$ $\left.\mathrm{Me}_{5}\right) \mathrm{W}(\mu-\mathrm{O})_{2} \mathrm{Os}_{3}(\mu-\mathrm{CCPh})(\mathrm{CO})_{9}(\mathbf{1})$, which possesses two edge-bridging oxo groups and an acetylide ligand in a $\mu-\eta^{2}$ mode, has been obtained by addition of $\left(\mathrm{C}_{5} \mathrm{Me}_{5}\right) \mathrm{W}$ $(\mathrm{O})_{2}(\mathrm{CCPh})$ to $\mathrm{Os}_{3}(\mathrm{CO})_{10}(\mathrm{NCMe})_{2}$. The subsequent re activity studies led to the isolation of $\mathrm{Cp}^{*} \mathrm{~W}(\mu-\mathrm{O})_{2} \mathrm{Os}_{3}(\mu-$ $\mathrm{H})(\mathrm{CO})_{9}$ (2) and $\mathrm{Cp} * \mathrm{~W}(\mathrm{O})(\mu-\mathrm{O}) \mathrm{Os}_{3}(\mathrm{CCPh})(\mathrm{CO})_{9}$ (3) through hydrogenation and treatment with pressurized CO, respectively. The structures of $\mathbf{1}$ and $\mathbf{3}$ reveal two distinctive bonding modes for the $\left.\left(\mathrm{C}_{5} \mathrm{Me}\right)_{5}\right) \mathrm{W}\left(\mathrm{O}_{2}\right.$ fragment on an $\mathrm{Os}_{3}$ skeleton.

Organometallic complexes containing oxo ligands serve as realistic models for metal-mediated oxidation and other homogeneous and heterogeneous reactions with high-valent metal species as catalysts. ${ }^{1}$ As a result, a large number of transition-metal oxo complexes have been synthesized; their reactivities with organic substrates have been explored. ${ }^{2}$ The critical information obtained has hel ped chemists to better understand the mechanism of these oxidation reactions catalyzed by discrete oxometal complexes. ${ }^{3}$ Alternatively, the second approach is to synthesize complexes bearing both oxo and hydrocarbyl ligands and to examine the role of oxo ligands on the chemical reactivity of such complexes. The investigation on the chemistry of a heterometallic complex with the formula $\mathrm{CpW}(\mu-\mathrm{O}) \mathrm{Os}_{3}\left(\mu_{3}-\mathrm{CCH}_{2} \mathrm{Tol}\right)$ $(\mathrm{CO})_{9},{ }^{4}$ which was prepared from the direct $\mathrm{C}-\mathrm{O}$ bond

\footnotetext{
${ }^{\dagger}$ National Tsing Hua University.

₹ National Research Council Canada.

$\S$ National Taiwan University.

\& Abstract published in AdvanceACS Abstracts, November 1, 1997.

(1) (a) Nugent, W. A.; Mayer, J . M. Metal-Ligand Multiple Bonds; Wiley-Interscience: New York, 1988. (b) Bottomley, F.; Sutin, L. Adv. Organomet. Chem. 1988, 28, 339. (c) Schauer, C. K.; Voss, E. J .; Sabat, M.; Shriver, D. F. J . Am. Chem. Soc. 1989, 111, 7662. (d) Atagi, L. M.; Over, D. E.; McAlister, D. R.; Mayer, J . M. J . Am. Chem. Soc. 1991, 113, 870. (e) Legzdins, P.; Phillips, E. C.; Rettig, S. J.; Trotter, J .; Veltheer, J. E.; Yee, V. C. Órganometallics 1992, 11, 3104. (f) Dobbs, D. A.; Bergman, R. G. J . Am. Chem. Soc. 1993, 115, 3836. (g) Hao, L.; Xiao, J .; Vittal, J .; Puddephatt, R. J . Angew. Chem., Int. Ed. Engl. 1995, 34, 346. (h) Xiao, J .; Puddephatt, R. J . Coord. Chem. Rev. 1995, 143,
} 457.

(2) (a) Holm, R. H. Chem. Rev. 1987, 87, 1401. (b) Holm, R. H.; Donahue, J . P. Polyhedron 1993, 12, 571 . (c) Woo, L. K. Chem. Rev. 1993, 93, 1125. (d) Dickman, M. H.; Pope, M. T. Chem. Rev. 1994, 94, 569. (e) Herrmann, W. A.; Kuehn, F. E. Acc. Chem. Res. 1997, 30, 169.

(3) (a) Clarke, R.; Gahagan, M.; Mackie, R. K.; Foster, D. F.; ColeHamilton, D.J .; Nicol, M.; Montford, A. W.J . Chem. Soc. Dalton Trans. 1995, 1221. (b) Herrmann, W. A.; Fischer, R. W.; Rauch, M. U.; Scherer, W. J. Mol. Catal. 1994, 86, 243. (c) Herrmann, W. A. J . Organomet. Chem. 1995, 500, 149. (d) Herrmann, W. A.; Correia, J. D. G.; Kuehn, F. E.; Artus, G. R. J .; Romao, C. C. Chem. Eur. J . 1996, 2, 168. (e) Belgacem, J .; Kress, J .; Osborn, J . A. J . Mol. Catal. 1994, 86, 267.

(4) (a) Shapley, J. R.; Park, J .-T.; Churchill, M. R.; Ziller, J. W.; Beanan, L. R. J. Am. Chem. Soc. 1984, 106, 1144. (b) Park, J. T.; Shapley, J . R.; Churchill, M. R.; Bueno, C. Inorg. Chem. 1983, 22, 1579. cleavage of an acyl functional group, provides a remarkable milestone of this indirect approach.

In this study, we wish to report the synthesis and identification of three $\mathrm{WOs}_{3}$ cluster complexes which were prepared from a sequence initiated by combining the dioxo acetylide complex $\left(\mathrm{C}_{5} \mathrm{Me}_{5}\right) \mathrm{W}(\mathrm{O})_{2}(\mathrm{CCPh})^{5}$ and the lightly stabilized triosmium complex $\mathrm{Os}_{3}(\mathrm{CO})_{10^{-}}$ (NCMe $)_{2} \cdot{ }^{6}$ The products obtained inherit a $\left(\mathrm{C}_{5} \mathrm{Me}_{5}\right) \mathrm{W}$ $(\mathrm{O})_{2}$ fragment from their starting materials; therefore, their structural and reactivity properties would differ greatly from those of the previously reported $\mathrm{WO}_{3}$ oxoalkylidyne compounds ${ }^{4}$ as well as our $\mathrm{WRe}_{2}$ and WRe oxo-acetylide complexes, ${ }^{7}$ which possess only one oxo ligand in either an edge-bridging or terminal mode.

\section{Experimental Section}

General Information and Materials. Infrared spectra were recorded on a Perkin-E Imer 2000 FT-IR spectrometer. ${ }^{1} \mathrm{H}$ and ${ }^{13} \mathrm{C}$ NMR spectra were recorded on a Bruker AM-400 (400.13 M Hz) or a Bruker AMX-300 (300.6 MHz) instrument. Mass spectra were obtained on a J EOL-HX110 instrument operating in the fast atom bombardment mode (FAB). All reactions were performed under a nitrogen atmosphere using solvents dried with an appropriate reagent. The products were separated on commercially available preparative thin-layer chromatographic plates (Kieselgel $60 \mathrm{~F}_{254}, \mathrm{E}$. Merck). Elemental analyses were performed at the NSC Regional Instrumentation Center at National Cheng Kung University, Tainan, Taiwan.

Reaction of $\mathrm{Os}_{3}(\mathrm{CO})_{10}(\mathrm{NCMe})_{2}$ with $\left(\mathrm{C}_{5} \mathrm{Me}_{5}\right) \mathrm{W}(\mathrm{O})_{2^{-}}$ (CCPh). A toluene solution $(60 \mathrm{~mL})$ of $\mathrm{Os}_{3}(\mathrm{CO})_{10}(\mathrm{NCMe})_{2}(247$ $\mathrm{mg}, 0.265 \mathrm{mmol})$ and $\left(\mathrm{C}_{5} \mathrm{Me}_{5}\right) \mathrm{W}(\mathrm{O})_{2}(\mathrm{CCPh})(100 \mathrm{mg}, 0.224$ mmol) was heated at $80{ }^{\circ} \mathrm{C}$ for $30 \mathrm{~min}$. The solvent was removed under vacuum, the mixture was dissolved in a minimum amount of $\mathrm{CH}_{2} \mathrm{Cl}_{2}$, and this solution was subjected to thin-layer chromatography with a $1: 1$ mixture of $\mathrm{CH}_{2} \mathrm{Cl}_{2}$ and hexane, affording $160 \mathrm{mg}$ of orange $\left(\mathrm{C}_{5} \mathrm{Me}_{5}\right) \mathrm{W}(\mu-\mathrm{O})_{2} \mathrm{Os}_{3^{-}}$ $(\mu-\mathrm{CCPh})(\mathrm{CO})_{9}(\mathbf{1} ; 0.125 \mathrm{mmol}, 56 \%)$. Crystals of complex $\mathbf{1}$ suitable for $\mathrm{X}$-ray diffraction study were recrystallized from a mixture of $\mathrm{CH}_{2} \mathrm{Cl}_{2}$ and methanol at room temperature.

Spectral data for $\mathbf{1}$ are as follows. MS (FAB, $\left.{ }^{184} \mathrm{~W},{ }^{192} \mathrm{Os}\right)$ : $\mathrm{m} / \mathrm{z} 1280\left(\mathrm{M}^{+}\right)$. IR $\left(\mathrm{C}_{6} \mathrm{H}_{12}\right): v(\mathrm{CO}) 2088(\mathrm{~m}), 2069$ (vs), 2026 (vs), 2003 (s, br), 1969 (m), 1933 (w) cm ${ }^{-1} .{ }^{1} \mathrm{H}$ NMR (300 MHz, $\left.\mathrm{CDCl}_{3}, 297 \mathrm{~K}\right): \delta 7.38-7.20(\mathrm{~m}, 5 \mathrm{H}), 2.12(\mathrm{~s}, 15 \mathrm{H}) .{ }^{13} \mathrm{C} N \mathrm{NMR}$ $\left(75 \mathrm{MHz} \mathrm{CDCl}_{3}, 297 \mathrm{~K}\right): \delta 186.8(1 \mathrm{CO}, \mathrm{J} w c=9 \mathrm{~Hz}), 185.1$ (2CO), 178.3 (2CO), 172.8 (2CO), 169.5 (2CO); $\delta 130.9$ (2C, o- $\left.\mathrm{C}_{6} \mathrm{H}_{5}\right), 128.5\left(1 \mathrm{C}, \mathrm{p}-\mathrm{C}_{6} \mathrm{H}_{5}\right), 128.4\left(2 \mathrm{C}, \mathrm{m}-\mathrm{C}_{6} \mathrm{H}_{5}\right), 127.9$ (1C,

(5) Shiu, C.-H.; Su, C.-J .; Pin, C.-W.; Chi, Y.; Peng, S.-M.; Lee, G.H. J. Organomet. Chem., in press.

(6) Nicholls, J. N.; Vargas, M. D. Inorg. Synth. 1990, 28, 232.

(7) (a) Chi, Y.; Cheng, P.-S.; Wu, H.-L.; Hwang, D.-K.; Peng, S.-M .; Lee, G.-H. J . Chem. Soc., Chem. Commun. 1994, 1839. (b) Lai, N.-S.; Tu, W.-C.; Chi, Y.; Peng, S.-M.; Lee, G.-H. Organometallics 1994, 13, 4652. (c) Chi, Y.; Wu, H.-L.; Chen, C.-C.; Su, C.-J .; Peng, S.-M.; Lee, G.-H. Organometallics 1997, 16, 2443. 
i- $\left.\mathrm{C}_{6} \mathrm{H}_{5}\right), 115.8\left(\mathrm{C}_{5} \mathrm{Me}_{5}\right), 102.9(\mathrm{CCPh}), 75.6(\mathrm{CCPh}), 12.2$ $\left(\mathrm{C}_{5} \mathrm{Me} \mathrm{e}_{5}\right.$ ). Anal. Calcd for $\mathrm{C}_{27} \mathrm{H}_{20} \mathrm{O}_{11} \mathrm{Os}_{3} \mathrm{~W}$ : C, 25.31; $\mathrm{H}, 1.57$. Found: C, 25.31; $\mathrm{H}, 1.61$.

Hydrogenation of 1. A toluene solution $(30 \mathrm{~mL})$ of $\left(\mathrm{C}_{5}-\right.$ $\left.\mathrm{Me}_{5}\right) \mathrm{W}(\mu-\mathrm{O})_{2} \mathrm{Os}_{3}(\mu-\mathrm{CCPh})(\mathrm{CO})_{9}(\mathbf{1} ; 107 \mathrm{mg}, 0.084 \mathrm{mmol})$ was heated under a hydrogen atmosphere $(50 \mathrm{psig})$ at $100{ }^{\circ} \mathrm{C}$ for 2 $\mathrm{h}$, during which the color changed from orange to orange-red. After removal of the solvent in vacuo, the residue was taken up in $\mathrm{CH}_{2} \mathrm{Cl}_{2}$ and subjected to chromatographic workup on TLC plates using a 1:1 mixture of $\mathrm{CH}_{2} \mathrm{Cl}_{2}$ and hexane, giving $38 \mathrm{mg}$ of orange-red $\left(\mathrm{C}_{5} \mathrm{Me}_{5}\right) \mathrm{W}(\mu-\mathrm{O})_{2} \mathrm{Os}_{3}(\mu-\mathrm{H})(\mathrm{CO})_{9}(2 ; 0.032$ $\mathrm{mmol}, 39 \%)$. Crystals of $\mathbf{2}$ were obtained from a mixture of $\mathrm{CH}_{2} \mathrm{Cl}_{2}$ and methanol at room temperature.

Spectral data for 2 are as follows. MS (FAB, $\left.{ }^{184} \mathrm{~W},{ }^{192} \mathrm{OS}\right)$ : $\mathrm{m} / \mathrm{z} 1180\left(\mathrm{M}^{+}\right)$. IR $\left(\mathrm{C}_{6} \mathrm{H}_{12}\right): v(\mathrm{CO}) 2094(\mathrm{~m}), 2069(\mathrm{~s}), 2056$ (vw), 2024 (vs), 2013 (s), 2005 (m), 1987 (w), 1958 (m), 1936 (m) $\mathrm{cm}^{-1}$. ${ }^{1} \mathrm{H} N M R\left(300 \mathrm{MHz} \mathrm{CDCl}_{3}, 297 \mathrm{~K}\right): \delta 2.07(\mathrm{~s}, 15 \mathrm{H})$, $-15.71(\mathrm{~s}, 1 \mathrm{H}) ;{ }^{13} \mathrm{C}$ NMR $\left(75 \mathrm{MHz}, \mathrm{CDCl}_{3}, 297 \mathrm{~K}\right)$; $\mathrm{CO} \delta 192.6$, 184.0 (2CO), 174.7 (2CO), 172.0 (2CO), 169.1 (2CO); $\delta 116.5$ $\left(\mathrm{C}_{5} \mathrm{Me}_{5}\right), 11.8\left(\mathrm{C}_{5} \mathrm{Me}\right)$. Anal. Calcd for $\mathrm{C}_{19} \mathrm{H}_{16} \mathrm{O}_{11} \mathrm{Os}_{3} \mathrm{~W}$ : C, 19.43; $\mathrm{H}, 1.37$. Found: $\mathrm{C}, 19.49 ; \mathrm{H}, 1.41$.

Treatment of 1 with CO. A toluene solution (35 mL) of $\left(\mathrm{C}_{5} \mathrm{Me}_{5}\right) \mathrm{W}(\mu-\mathrm{O})_{2} \mathrm{Os}_{3}(\mu-\mathrm{CCPh})(\mathrm{CO})_{9}(\mathbf{1} ; 107 \mathrm{mg}, 0.084 \mathrm{mmol})$ was placed in a $100 \mathrm{~mL}$ stainless steel Parr high-pressure reactor and then charged with 800 psig of $\mathrm{CO}$ atmosphere. After the temperature was increased to $80^{\circ} \mathrm{C}$, the solution was continuously stirred for $2 \mathrm{~h}$. The CO was then released, and the solvent was removed in vacuo; the residue was taken up in $\mathrm{CH}_{2} \mathrm{Cl}_{2}$ and separated by thin-layer chromatography $\left(1: 1 \mathrm{CH}_{2-}\right.$ $\mathrm{Cl}_{2}$-hexane), giving $87 \mathrm{mg}$ of orange $\left.\left(\mathrm{C}_{5} \mathrm{Me}\right)_{5}\right) \mathrm{W}(\mathrm{O})(\mu-\mathrm{O})$ $\mathrm{Os}_{3}(\mathrm{CCPh})(\mathrm{CO})_{11}(3 ; 0.065 \mathrm{mmol}, 77 \%)$ and $7 \mathrm{mg}$ of $\left(\mathrm{C}_{5} \mathrm{Me}_{5}\right) \mathrm{W}$ $(\mathrm{O})_{2}(\mathrm{CCPh})(0.016 \mathrm{mmol}, 19 \%)$. Crystals suitable for X-ray diffraction study were recrystallized from a mixture of $\mathrm{CHCl}_{3}$ and methanol at room temperature.

Spectral data for $\mathbf{3}$ are as follows. MS (FAB, $\left.{ }^{184} \mathrm{~W},{ }^{192} \mathrm{Os}\right)$ : $\mathrm{m} / \mathrm{z} 1336\left(\mathrm{M}^{+}\right)$. IR $\left(\mathrm{C}_{6} \mathrm{H}_{12}\right): v(\mathrm{CO}) 2119(\mathrm{w}), 2092$ (vs), 2045 (vs), 2019 (vs), 2012 (s), 1989 (s), 1979 (m), 1975 (w), 1967 (vw), $1958(\mathrm{vw}) \mathrm{cm}^{-1}, v(\mathrm{CC}) 2141(\mathrm{vw}) \mathrm{cm}^{-1}$. ${ }^{1} \mathrm{H}$ NMR $(300 \mathrm{MHz}$, $\left.\mathrm{CDCl}_{3}, 297 \mathrm{~K}\right): \delta 7.25(\mathrm{~d}, 2 \mathrm{H}, \mathrm{J} \mathrm{HH}=7.3 \mathrm{~Hz}), 7.17(\mathrm{t}, 2 \mathrm{H}, \mathrm{J} \mathrm{HH}$ $=7.3 \mathrm{~Hz}), 7.06(\mathrm{t}, 1 \mathrm{H}, \mathrm{J} \mathrm{HH}=7.3 \mathrm{~Hz}), 2.10(\mathrm{~s}, 15 \mathrm{H}) .{ }^{13} \mathrm{C} \mathrm{NMR}$ (75 $\mathrm{MHz} \mathrm{CDCl}_{3}, 297 \mathrm{~K}$ ): $\mathrm{CO} \delta$ 193.3, 189.0, 186.9, 183.5, 178.9, $177.7(2 \mathrm{C}), 176.7,174.5,173.1,162.7 ; \delta 131.4(2 \mathrm{C}$, o- $\left.\mathrm{C}_{6} \mathrm{H}_{5}\right), 127.7\left(2 \mathrm{C}, \mathrm{m}-\mathrm{C}_{6} \mathrm{H}_{5}\right), 127.1\left(1 \mathrm{C}, \mathrm{i}-\mathrm{C}_{6} \mathrm{H}_{5}\right), 125.7$ (1C, $\left.\mathrm{p}-\mathrm{C}_{6} \mathrm{H}_{5}\right), 117.1\left(\mathrm{C}_{5} \mathrm{Me}_{5}\right), 112.2$ (CCPh), 65.3 (CCPh), 11.5 ( $\left.\mathrm{C}_{5} \mathrm{Me}_{5}\right)$. Anal. Calcd for $\mathrm{C}_{29} \mathrm{H}_{20} \mathrm{O}_{13} \mathrm{Os}_{3} \mathrm{~W}$ : C, 26.17; $\mathrm{H}, 1.51$. Found: C, 26.08; H, 1.59 .

Thermolysis of 3. A toluene solution $(30 \mathrm{~mL})$ of $\mathbf{3}(48 \mathrm{mg}$, $0.036 \mathrm{mmol}$ ) was heated at $100^{\circ} \mathrm{C}$ for $2 \mathrm{~h}$, during which time the color changed from yellow to light orange. The solvent was evaporated in vacuo, and the residue was dissolved in 3 $\mathrm{mL}$ of $\mathrm{CH}_{2} \mathrm{Cl}_{2}$. Workup of the mixture on TLC plates using a 1:2 mixture of dichloromethane and hexane gave $32 \mathrm{mg}$ of $\mathbf{1}$ $(0.024 \mathrm{mmol}, 67 \%)$ followed by $2 \mathrm{mg}$ of unreacted $3(0.002$ $\mathrm{mmol}, 4 \%$ ).

X-ray Crystallography. The X-ray diffraction measurements were carried out on a Nonius CAD-4 diffractometer at room temperature. Lattice parameters were determined from 25 randomly selected high-angle reflections. Three standard reflections were monitored every $3600 \mathrm{~s}$. No significant change in intensities $(\leq 2 \%)$ was observed during the course of data collection. Intensities of the diffraction signals were corrected for Lorentz, polarization, and absorption effects ( $\psi$ scans). The structure was solved by using the NRCC-SDP-VAX package. All of the non-hydrogen atoms had anisotropic temperature factors, while the hydrogen atoms of the organic substituents were placed at the calculated positions with $U_{H}=U_{C}+0.1$. The crystallographic refinement parameters of complexes $\mathbf{1}$ and $\mathbf{3}$ are given in Table $\mathbf{1}$, while their selected bond distances and angles are presented in Tables 2 and 3, respectively.
Table 1. X-ray Structural Data for Complexes 1 and $3^{a}$

\begin{tabular}{|c|c|c|}
\hline compd & 1 & 3 \\
\hline formula & $\mathrm{C}_{27} \mathrm{H}_{20} \mathrm{O}_{11} \mathrm{Os}_{3} \mathrm{~W}$ & $\mathrm{C}_{29} \mathrm{H}_{20} \mathrm{O}_{13} \mathrm{O}_{3} \mathrm{~W}$ \\
\hline cryst syst & $\begin{array}{l}12 / 4.88 \\
\text { orthorhombic }\end{array}$ & $\begin{array}{l}\text { 1330.91 } \\
\text { monoclinic }\end{array}$ \\
\hline space group & Pbca & $\mathrm{P} 2_{1} / \mathrm{n}$ \\
\hline$a(\AA)$ & $18.392(8)$ & $12.417(4)$ \\
\hline$b(\AA)$ & $19.453(4)$ & $12.468(5)$ \\
\hline$c(\AA)$ & $33.906(9)$ & $21.896(3)$ \\
\hline$\beta$ (deg) & & $95.26(3)$ \\
\hline$V\left(\AA^{3}\right)$ & $12131(7)$ & $3376(2)$ \\
\hline Z & 16 & 4 \\
\hline$D_{c}\left(g / \mathrm{cm}^{3}\right)$ & 2.792 & 2.619 \\
\hline$F(000)$ & 9068 & 2379 \\
\hline $2 \theta(\max )(\mathrm{deg})$ & 45.0 & 50.0 \\
\hline hkl ranges & $0-19,0-20,0-36$ & -14 to $14,0-14,0$ \\
\hline cryst size $(\mathrm{mm})$ & $0.30 \times 0.40 \times 0.50$ & $0.05 \times 0.20 \times 0.25$ \\
\hline$\mu(\operatorname{MoK} \alpha)\left(\mathrm{cm}^{-1}\right)$ & 164.62 & 147.95 \\
\hline transmission: $\max , \min$ & $1.000,0.607$ & $1.000,0.371$ \\
\hline no. of data in refinement & 3653 with $I \geq 2 \sigma(I)$ & 3064 with $I \geq 2 \sigma(I)$ \\
\hline no. of atoms and params & 124,758 & 66,416 \\
\hline weight modifier, $\mathrm{g}$ & 0.00001 & 0.0001 \\
\hline $\max \Delta / \sigma$ ratio & 0.045 & 0.020 \\
\hline $\mathrm{R}_{\mathrm{F}} ; \mathrm{R}_{\mathrm{W}}$ & $0.054 ; 0.051$ & $0.041 ; 0.039$ \\
\hline GOF & 1.52 & 1.39 \\
\hline D map, $\max / \min \left(e / \AA^{3}\right)$ & $+2.42 /-2.19$ & $+1.79 /-1.58$ \\
\hline
\end{tabular}

a Features common to all determinations: Nonius CAD-4 diffractometer, $\lambda(\mathrm{M} \circ \mathrm{K} \alpha)=0.7107 \AA$; function minimized $\sum\left(\mathrm{w} \mid \mathrm{F}_{0}-\right.$ $\left.\mathrm{F}_{\mathrm{c}}{ }^{2}\right)$; weighting scheme $\mathrm{w}^{-1}=\sigma^{2}\left(\mathrm{~F}_{\mathrm{o}}\right)+|\mathrm{g}| \mathrm{F}_{\mathrm{o}}{ }^{2} ; \mathrm{GOF}=\left[\Sigma \mathrm{w} \mid \mathrm{F}_{\mathrm{o}}-\right.$ $\left.\mathrm{FCl}_{\mathrm{c}}^{2} /\left(\mathrm{N}_{\mathrm{o}}-\mathrm{N}_{\mathrm{v}}\right)\right]^{1 / 2}\left(\mathrm{~N}_{\mathrm{o}}=\right.$ number of observations; $\mathrm{N}_{\mathrm{v}}=$ number of variables).

Table 2. Selected Bond Distances $(\AA)$ and Angles (deg) of 1 (Esd's in Parentheses)

\begin{tabular}{|c|c|c|c|}
\hline W-Os(1) & $2.981(2)$ & W-Os(2) & $3.014(2)$ \\
\hline $\mathrm{W}-\mathrm{Os}(3)$ & $2.603(3)$ & 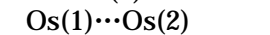 & $3.841(3)$ \\
\hline Os(1)-Os(3) & $2.891(2)$ & $\mathrm{Os}(2)-\mathrm{Os}(3)$ & $2.938(3)$ \\
\hline $\mathrm{W}-\mathrm{O}(10)$ & $1.76(2)$ & $\mathrm{W}-\mathrm{O}(11)$ & $1.76(3)$ \\
\hline $\mathrm{Os}(1)-\mathrm{O}(10)$ & $2.10(2)$ & $O s(2)-O(11)$ & $2.16(2)$ \\
\hline Os(1)-C(10) & $2.13(4)$ & $\mathrm{Os}(2)-\mathrm{C}(10)$ & $2.34(3)$ \\
\hline $\mathrm{Os}(2)-\mathrm{C}(11)$ & $2.33(4)$ & $C(10)-C(11)$ & $1.11(5)$ \\
\hline $\begin{array}{l}\angle \mathrm{W}-\mathrm{O}(10)-\mathrm{Os}(1) \\
\angle \mathrm{Os}(1)-\mathrm{C}(10)-\mathrm{C}(11\end{array}$ & $\begin{array}{l}101(1) \\
163(3)\end{array}$ & $\begin{array}{l}\angle \mathrm{W}-\mathrm{O}(11)-\mathrm{Os}(2) \\
\angle \mathrm{C}(10)-\mathrm{C}(11)-\mathrm{C}(12\end{array}$ & $00(1)$ \\
\hline
\end{tabular}

Table 3. Selected Bond Distances $(\AA)$ and Angles (deg) of 3 (Esd's in Parentheses)

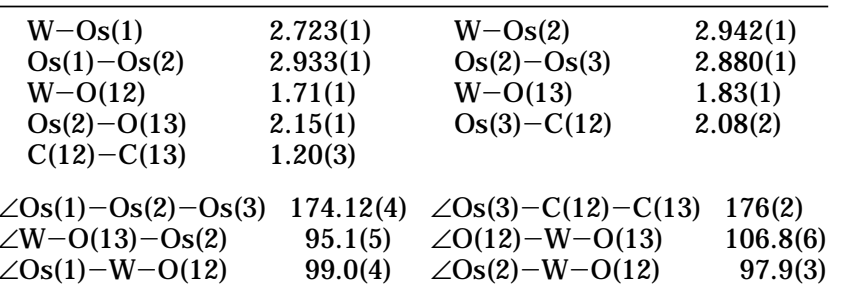

\section{Results and Discussion}

As indicated in Scheme 1, the heterometall ic acetylide cluster compound $\left(\mathrm{C}_{5} \mathrm{Me}_{5}\right) \mathrm{W}(\mu-\mathrm{O})_{2} \mathrm{Os}_{3}(\mu-\mathrm{CCPh})(\mathrm{CO})_{9}(\mathbf{1})$, which possesses two edge-bridging oxo ligands, was prepared by addition of the mononuclear acetylide precursor $\left(\mathrm{C}_{5} \mathrm{Me}_{5}\right) \mathrm{W}(\mathrm{O})_{2}(\mathrm{CCPh})$ to the bis(acetonitrile) complex $\mathrm{Os}_{3}(\mathrm{CO})_{10}(\mathrm{NCMe})_{2}$. This high-yield conversion to the isolated 1:1 adduct clearly shows the effective coordination of the acetylide ligand to an Os atom of the triosmium triangle at the initial stage of reaction, which is evidenced by the facile coordination of alkyne to $\mathrm{Os}_{3}(\mathrm{CO})_{10}(\mathrm{NCMe})_{2}{ }^{8}$ We anticipate that the el ectronwithdrawing capability of the $\left(\mathrm{C}_{5} \mathrm{Me}\right)_{5} \mathrm{~W}(\mathrm{O})_{2}$ fragment decreases the relative energy of the acetylide $\pi^{*}$-orbitals

(8) (a) Aime, S.; Deeming, A. J . J . Chem. Soc., Dalton Trans. 1983, 1807. (b) Deeming, A. J .; Senior, A. M. J . Organomet. Chem. 1992, 439, 177. 
Scheme 1

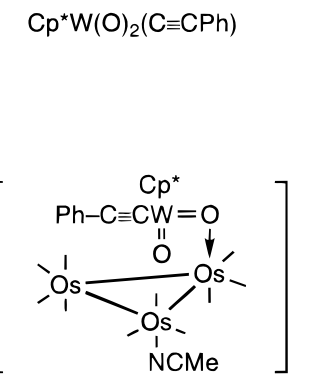

$$
+\quad \mathrm{Os}_{3}(\mathrm{CO})_{10}(\mathrm{NCMe})_{2}
$$
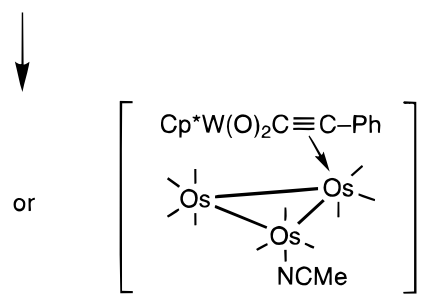<smiles>CC(C)(C)C</smiles>

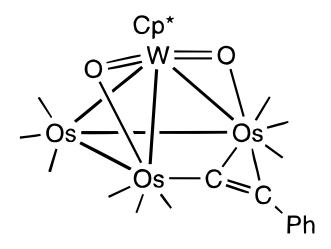

(1)

$$
+c o \downarrow \uparrow-c o
$$

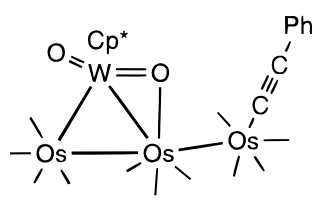

(3)

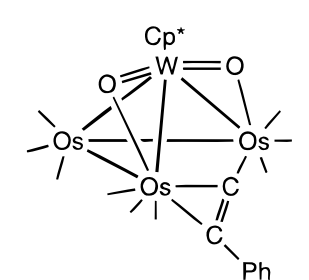

(1)

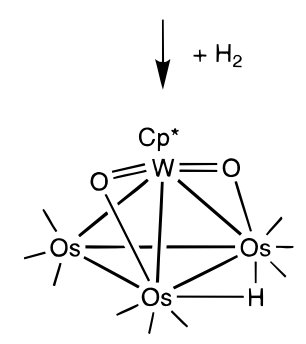

(2) and therefore increases the metal-to-acetylide ligand back- $\pi$-bonding, serving as the key factor in improving the yiel ds with respect to the poor yields $(\sim 11 \%)$ for the similar cluster-building reactions using $\left(\mathrm{C}_{5} \mathrm{Me}_{5}\right) \mathrm{W}(\mathrm{CO})_{3^{-}}$ $(\mathrm{CCPh})$ and $\mathrm{Os}_{3}(\mathrm{CO})_{10}(\mathrm{NCMe})_{2} \cdot{ }^{9}$ The second possibility involves the prior coordination of the oxo ligand lone pair with the triosmium framework, which then induces the subsequent capping of the acetylide ligand. This reaction pathway is supported by examples in the literature where coordination of a lone pair is the initial step in the reaction of $\mathrm{Os}_{3}(\mathrm{CO})_{10}(\mathrm{NCMe})_{2}$ with donor molecules and where $\mathrm{C}-\mathrm{H}$ and $\mathrm{C}-\mathrm{X}$ bonds are also activated. ${ }^{10}$ We cannot differentiate these two possibilities at present; however, it is certain that the transformation was completed by the deavage of the $\mathrm{W}-\mathrm{C}$ (acetylide) $\sigma$-bonding and generation of the observed Os$\mathrm{C}$ (acetylide) $\sigma$-interaction and strengthening of the bonding between the $\left(\mathrm{C}_{5} \mathrm{Me}_{5}\right) \mathrm{W}(\mathrm{O})_{2}$ fragment and the triosmium framework.

According to the X-ray diffraction analysis, complex 1 was crystallized in an asymmetric unit possessing two crystallographically distinct but structurally similar molecules. A perspective view of one of these molecules

(9) (a) Chi, Y.; Lee, G.-H.; Peng, S.-M.; Wu, C.-H. Organometallics 1989, 8, 1574 . (b) Chi, Y.; Wu, C.-H.; Peng, S.-M.; Lee, G.-H. Organometallics 1990, 9, 2305. (c) Su, P.-C.; Chiang, S.-- .; Chang, L.-L.; Chi, Y.; Peng, S.-M.; Lee, G.-H. Organometallics 1995, 14, 4844. (d) Chi, Y.; Chung, C.; Chou, Y.-C.; Su, P.-C.; Chiang, S.-J .; Peng, S.M.; Lee, G.-H. Organometallics 1997, 16, 1702.

(10) (a) Day, M.; Espitia, D.; Hardcastle, K. I.; Kabir, S. E.; McPhillips, T.; Rosenberg, E.; Gobetto, R.; Milone, L.; Osella, D. Organometallics 1993, 12, 2309. (b) Azam, K. A.; Dilshad, R.; Kabir, S. E.; Khatoon, K.; Nessa, L.; Rahman, M. M.; Rosenberg, E.; Hursthouse, M. B.; Malik, K. M. A.; Deeming, A. J . J . Chem. Soc., Dalton Trans. 1996, 1731.

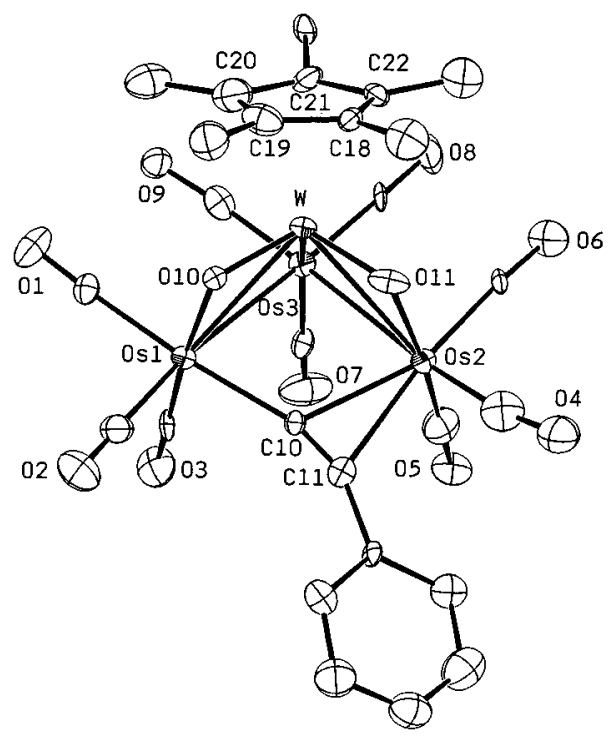

Figure 1. Molecular structure and atomic labeling scheme of the complex $\left(\mathrm{C}_{5} \mathrm{Me}_{5}\right) \mathrm{W}(\mu-\mathrm{O})_{2} \mathrm{Os}_{3}(\mu-\mathrm{CCPh})(\mathrm{CO})_{9}$ (1) with thermal ellipsoids shown at the $30 \%$ probability level.

is depicted in Figure 1. The molecule contains a $\mathrm{WOs}_{3}$ butterfly core in which the tungsten atom is capped by a $\mathrm{C}_{5} \mathrm{Me}_{5}$ functional group, while each of the osmium atoms is linked to three terminal CO ligands. An unusual feature is the bridging oxo ligands, which are located on the two $\mathrm{W}-\mathrm{Os}$ bonds of nearly equal length (2.981(2) and 3.014(2) $\AA$ ). The bond lengths to the oxo ligands (average $\mathrm{W}-\mathrm{O}=1.76(3) \AA$, Os $-\mathrm{O}=2.13(3) \AA$ ) are similar to that of the $\mathrm{W}=\mathrm{O} \rightarrow \mathrm{O}$ s bonding mode, ${ }^{11}$ and the average $\mathrm{Os}-\mathrm{O}$ distance is slightly longer than the Os-O distance $(2.06(2) \AA)$ in $\mathrm{Os}_{6}\left(\mu_{3}-\mathrm{O}\right)\left(\mu_{3}-\mathrm{CO}\right)(\mathrm{CO})_{18}{ }_{12}$ and $\left[\mathrm{Os}\left(\mu_{3}-\mathrm{O}\right)(\mathrm{CO})_{3}\right]_{4}{ }^{13}$ In addition, the $\mathrm{W}-\mathrm{Os}(3)$ distance (2.603(3) $\AA$ ) is significantly shorter than the other $\mathrm{W}-$ Os distances which support the bridging oxo ligands. In fact, this W-Os distance is the shortest W-Os single bond ever observed in the related W-Os carbonyl cluster complexes. ${ }^{14}$ We believe that this unusually short W-Os distance is caused by a combined effect of the contraction of the atomic radius for the tungsten atom due to the greater formal nuclear charge and the lack of a bridging oxo ligand.

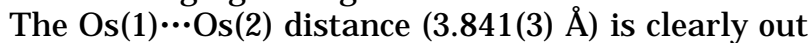
of the range expected for an Os-Os single bond; e.g., the average Os-Os distance in $\mathrm{Os}_{3}(\mathrm{CO})_{12}$ is $2.877(1) \AA .{ }^{15}$ The acetylide ligand is linked to the Os(1) and the Os-

(11) (a) Churchill, M. R.; Bueno, C.; Park, J . T.; Shapley, J . R. Inorg Chem. 1984, 23, 1017. (b) Chi, Y.; Shapley, J . R.; Churchill, M. R.; Li, Y.-J . Inorg. Chem. 1986, 25, 4165. (c) Chi, Y.; Shapley, J . R.; Ziller, J. W.; Churchill, M. R. Organometallics 1987, 6, 301. (d) Park, J -T.; Chung, M.-K.; Chun, K. M.; Yun, S. S.; Kim, S. Organometallics 1992, 11, 3313. (e) Gong, J .-H.; Chen, C.-C.; Chi, Y.; Wang, S.-L.; Liao, F.L. J . Chem. Soc., Dalton Trans. 1993, 1829. (f) Park, J . T.; Chi, Y. Shapley, J . R.; Churchill, M. R.; Ziller, J . W. Organometallics 1994, $13,813$.

(12) Goudsmit, R. J .; J ohnson, B. F. G.; Lewis, J .; Raithby, P. R.; Whitmire, K. H. J . Chem. Soc., Chem. Commun. 1983, 246.

(13) Bright, D. J . Chem. Soc. D 1970, 1169.

(14) (a) Churchill, M. R.; Hollander, F.J .; Shapley, J . R.; Foose, D. S. J . Chem. Soc., Chem. Commun. 1978, 534. (b) Park, J. T.; Shapley, J. R.; Bueno, C.; Ziller, J .W.; Churchill, M. R. Organometallics 1988, 7, 2307. (c) Gong, J.-H.; Hwang, D.-K.; Tsay, C.-W.; Chi, Y.; Peng, S.-M.; Lee, G.-H. Organometallics 1994, 13, 1720. (d) Kuo, M.-T.; Hwang, D.-K.; Liu, C.-S.; Chi, Y.; Peng, S.-M.; Lee, G.-H. Organome tallics 1994, 13, 2142. (e) Gong, J .-H.; Tsay, C.-W.; Tu, W.-C.; Chi, Y.; Peng, S.-M.; Lee, G.-H. J . Cluster Sci. 1995, 6, 289. (f) Huang, T.-K.; Chi, Y.; Peng, S.-M.; Lee, G.-H.; Wang, S.-L.; Liao, F.-L. Organometallics 1995, 14, 2164.

(15) Churchill, M. R.; DeBoer, B. G. Inorg. Chem. 1977, 16, 878. 
(2) atoms via $\sigma$-bonding and $\pi$-interaction, respectively. Such $a \mu_{2}-\eta^{2}$ bonding interaction of an acetylide ligand has been observed in a few acetylide cluster complexes, ${ }^{16}$ but complex $\mathbf{1}$ indicates an uncommon instance where the acetylide fragment spans two nonbonding metal atoms with nearly identical $\pi$-bonding distances: Os$(2)-C(10)=2.34(3) \AA$ and $O s(2)-C(11)=2.33(4) \AA$. Moreover, the acetylide ligand undergoes a facile $\sigma \rightarrow$ $\pi, \pi \rightarrow \sigma$ rearrangement in solution (Scheme 1 ). This is suggested by the ${ }^{13} \mathrm{C}$ NMR spectrum, which exhibited five sharp CO resonances at $\delta 186.8(\mathrm{~J} \mathrm{wC}=9 \mathrm{~Hz}), 185.1$, $178.3,172.8$, and 169.5 in the ratio 1:2:2:2:2 at room temperature, suggesting the presence of a dynamic plane of mirror symmetry which bisects the whole molecule. This behavior is consistent with the fluxionality of edge-bridging alkenyl or acetylide ligands, ${ }^{17}$ which also showed similar $\sigma \rightarrow \pi, \pi \rightarrow \sigma$ exchanging between the two metal sites. When the temperature was lowered to $183 \mathrm{~K}$, the CO signals at $\delta 185.1,178.3$, and 169.5 split to form three pairs of very broad signals at $\delta 187.0$ and $182.8,178.8$ and 175.7, and 170.8 and 166.8. F rom the coal escence temperature of $198 \mathrm{~K}$, an estimated $\Delta G^{\ddagger}$ value of $9 \mathrm{kcal} / \mathrm{mol}$ is obtained for the activation energy barrier, which is slightly lower than that observed in the prior cases $(10-12 \mathrm{kcal} / \mathrm{mol}),{ }^{16 a}$ where the acetylide ligand undergoes exchange across two bonded metal atoms.

With respect to the reactivity of $\mathbf{1}$, the acetylide ligand can be easily removed upon treatment with dihydrogen, giving the compound $\left(\mathrm{C}_{5} \mathrm{Me}_{5}\right) \mathrm{W}(\mu-\mathrm{O})_{2} \mathrm{Os}_{3}(\mathrm{CO})_{9}(\mu-\mathrm{H})(\mathbf{2})$, in which the metal skeleton now adopts a tetrahedral arrangement with a hydride spanning the unique OsOs edge (Scheme 1). The mass spectrum of $\mathbf{2}$ gave a strong molecular ion. The ${ }^{1} \mathrm{H}$ NMR spectrum showed one high-field signal at $\delta-15.71$ for the hydrideligand. The five CO signals at $\delta$ 192.6, 184.0,174.7, 172.0, and 169.1 with the expected 1:2:2:2:2 ratio were observed in the ${ }^{13} \mathrm{C}$ NMR spectrum, suggesting the existence of $\mathrm{C}_{\mathrm{s}}$ symmetry. Most importantly, the IR $v(\mathrm{CO})$ spectrum showed a CO stretching pattern which is identical with that of the structurally characterized $\mathrm{Cp}$ complex CpW$\left.(\mu-\mathrm{O})_{2} \mathrm{Os}_{3}(\mathrm{CO})_{9}(\mu-\mathrm{H})\right)^{18}$ Thus, these spectroscopic data provide unambiguous confirmation for the proposed structure.

In addition to the hydrogenation reaction discussed, we also examined the reaction of $\mathbf{1}$ with carbon monoxide in order to better understand its reactivity. Thus, we isolated the spiked triangular complex $\left(\mathrm{C}_{5} \mathrm{Me}_{5}\right) \mathrm{W}$ -

(16) (a) Carty, A. J .; Taylor, N. J .; Smith, W. F. J . Chem. Soc., Chem. Commun. 1979, 750. (b) Carty, A. J .; MacLaughlin, S. A.; Wagner, J . V.; Taylor, N. J. Organometallics 1982, 1, 1013. (c) Cherkas, A. A.; Taylor, N. J .; Carty, A. J . J . Chem. Soc., Chem. Commun. 1990, 385. (d) Rosenberger, C.; Steunou, N.; J eannin, S.; J eannin, Y.J . Organomet. Chem. 1995, 494, 17. (e) Chi, Y.; Carty, A. J .; Blenkiron, P.; Delgado, E.; Enright, G. D.; Wang, W.; Peng, S.-M.; Lee, G.-H. Organometallics 1996, 15, 5269.

(17) (a) Cherkas, A. A.; Randall, L. H.; MacLaughlin, S. A.; Mott, G. N.; Taylor, N. J .; Carty, A. J . Organometallics 1988, 7, 969. (b) Chi, Y.; Chen, B.-F.; Wang, S.-L.; Chiang, R.-K.; Hwang, L.-S. J . Organomet. Chem. 1989, 377, C59. (c) Casey, C. P.; Crocker, M. Vosejpka, P. C.; Rheingold, A. L. Organometallics 1989, 8, 278. (d) Cherkas, A. A.; Randall, L. H.; Taylor, N. J .; Mott, G. N.; Yule, J . E.; Guinamant, J . L.; Carty, A. J . Organometallics 1990, 9, 1677. (e) Arce, A. J .; Manzur, M.; Marquez, M.; De Sanctis, Y.; Deeming, A. J .J . Organomet. Chem. 1991, 412, 177. (f) Bruce, M. I. Chem. Rev. 1991, 91, 197. (g) Adams, R. D.; Chen, G.; Qu, X.; Wu, W.; Yamamoto, J . H. J . Am. Chem. Soc. 1992, 114, 10977. (h) Farrugia, L. J .; Chi, Y.; Tu, W.-C. Organometallics 1993, 12, 1616. (i) Koike, M.; Hamilton, D. H.; Wilson, S. R.; Shapley, J . R. Organometallics 1996, 15, 4930.

(18) Chi, Y.; H wang, L.-S.; Lee, G.-H.; Peng, S.-M. J . Chem. Soc., Chem. Commun. 1988, 1456.

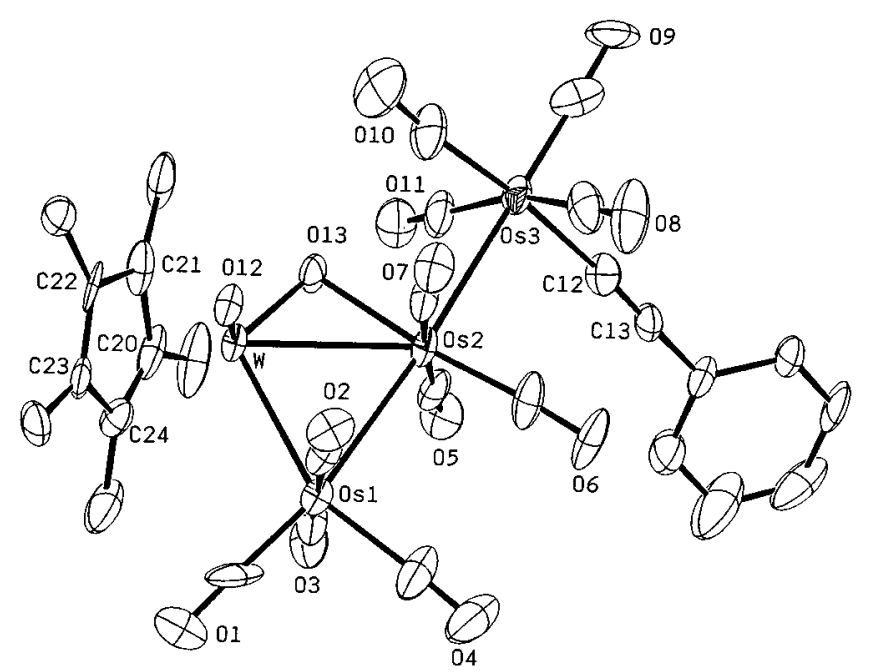

Figure 2. Molecular structure and atomic labeling scheme of the complex $\left(\mathrm{C}_{5} \mathrm{Me}_{5}\right) \mathrm{W}(\mathrm{O})(\mu-\mathrm{O}) \mathrm{Os}_{3}(\mathrm{CCPh})(\mathrm{CO})_{11}$ (3) with thermal ellipsoids shown at the $30 \%$ probability level.

$(\mathrm{O})(\mu-\mathrm{O}) \mathrm{Os}_{3}(\mathrm{CO})_{11}(\mathrm{CCPh})$ (3), which is produced by addition of two CO molecules (Scheme 1), and a small amount of acetylide complex $\left(\mathrm{C}_{5} \mathrm{Me}_{5}\right) \mathrm{W}(\mathrm{O})_{2}(\mathrm{CCPh})$, pre sumably produced by unwanted cluster degradation. Complex $\mathbf{3}$ was characterized by spectroscopic methods and by an X-ray diffraction study (Figure 2). The key features involve the formation of a terminal acetylide group on the Os(3) atom and the shifting of one edgebridging oxo ligand to the terminal mode, which is somewhat related to that observed in the cluster $\left(\mathrm{C}_{5}-\right.$ $\left.\mathrm{Me}_{5}\right) \mathrm{W}(\mathrm{O})_{2} \mathrm{Ru}_{4}(\mathrm{CO})_{10}\left(\mu_{4}-\mathrm{PPh}\right)(\mathrm{CCPh}){ }^{19}$ Again, the unbridged $\mathrm{W}-\mathrm{Os}(1)$ distance $(2.723(1) \AA)$ is the shortest metal-metal bond within the whole molecule (W-Os$(2)=2.942(1) \AA, O s(1)-O s(2)=2.933(1) \AA$, and Os(2)Os(3) $=2.880(1) \AA)$, a consequence related to the smaller atomic radius for the tungsten atom at the higher oxidation state. Finally, thermolysis of $\mathbf{3}$ in toluene afforded $\mathbf{1}$ in high yield. This reactivity pattern suggests that both the acetylide and the terminal oxo ligands are good multiple electron donors, ${ }^{7}$ which are capable of stabilizing the cluster by compensating the unsaturation created by $\mathrm{CO}$ elimination, via edgebridging (i.e. $\mu-\eta^{2}-\mathrm{CCPh}$ and $\mu$-O modes) through donation of their $\pi$-electrons and lone-pair electrons, respectively.

Acknowledgment. This work was supported by grants from the National Research Council of Canada, the Natural Sciences and Engineering Research Council of Canada (to A.J .C.), and the National Science Council of Taiwan (to Y.C.; Grant No. NSC 86-2113-M 007-035).

Supporting Information Available: Tables of atomic coordinates and the corresponding anisotropic thermal parameters for complexes $\mathbf{1}$ and $\mathbf{3}$ (12 pages). Ordering information is given on any current masthead page.

\section{OM970575D}

(19) Blenkiron, P.; Carty, A. J .; Peng, S.-M.; Lee, G.-H.; Su, C.-J .; Shiu, C.-W.; Chi, Y. Organometallics 1997, 16, 519. 